\title{
The Formation and Stabilization of Aerobic Granular Sludge in a Sequencing Batch Airlift Reactor for Treating Tapioca-Processing Wastewater
}

\author{
Phuong Thi Thanh Nguyen ${ }^{1}$, Phuoc Van Nguyen', \\ Hong Thi Bich Truong ${ }^{1,2}$, Ha Manh Bui ${ }^{3 *}$ \\ ${ }^{1}$ Insitute for Environment and Resources, Vietnam National University-Ho Chi Minh City, Vietnam \\ ${ }^{2}$ Departement of Engineering and Technology, Pham Van Dong University, Vietnam \\ ${ }^{3}$ Department of Environmental Sciences, Sai Gon University, Vietnam
}

Received: 1 April 2016

Accepted: 19 April 2016

\begin{abstract}
This study evaluated performance and granule features of a sequencing batch airlift reactor (SBAR) to treat tapioca-processing wastewater. The effect of organic loading rate (OLR) on the stabilization of aerobic granules was also investigated by increasing the OLR gradually from $2.5 \mathrm{kgCOD} / \mathrm{m}^{3}$.day to $10 \mathrm{kgCOD} / \mathrm{m}^{3}$.day. The results indicated that clear boundary granules were formed after a two-week cultivation period. The aerobic granules' average diameter increased according to rise in OLR and got a stable value of $2.5 \mathrm{~mm}$ at an OLR of $7.5 \mathrm{kgCOD} / \mathrm{m}^{3}$. day. The mature granules consisted of a dark core (anoxic) and yellow sludge surroundings (aerobic). The higher OLR led to forming granules of diameter 3-4 mm which were then broken due to substrate diffusion limitation. Aerobic granules could successfully treat organic substances, $\mathrm{NH}_{4}{ }^{+}-\mathrm{N}$, and phosphorus with high removal efficiencies of 93.9-96.3\%, 79.7-82.6\%, and $80-95 \%$, respectively. We observed that the aerobic granular sludge has good settling ability with a sludge volume index (SVI) lower than $50 \mathrm{~mL} / \mathrm{g}$, and is able to withstand high OLR. The experimental findings created a new prospect for granulation and employment of aerobic granules to treat industrial wastewater.
\end{abstract}

Keywords: aerobic granules, granulation, tapioca processing wastewater, organic substance removal, sequencing batch airlift reactor (SBAR) sequencing batch airlift reactor (SBAR)

\section{Introduction}

During the 1990s conventional aerobic biological processes for wastewater treatment - namely activated

*e-mail: manhhakg@yahoo.com.vn sludge, biofilter, and rotating biological reactor - were studied and applied in domestic and industrial wastewater treatment contexts. However, this technology has several disadvantages, such as low organic loading rates (0.5-2 $\mathrm{kgCOD} / \mathrm{m}^{3}$.day), shock loading, and high excess biomass concentration. In recent years the technological improvement studies have focused significantly on aerobic 
granular sludge, which has advantages that overcome the drawbacks of activated sludge such as settling velocity greater than $10 \mathrm{~m} / \mathrm{h}$ [1], SVI less than $35 \mathrm{~mL} / \mathrm{g}$ [2], and high organic loading rates of $15 \mathrm{~kg} \mathrm{COD} / \mathrm{m}^{3}$.day [3].

Aerobic granular sludge is defined as aggregate of microbial origin that does not coagulate under reduced hydrodynamic shear, and which settles significantly faster than activated sludge flocs. It is developed under aerobic conditions and mainly used for, firstly, the aerobic degradation of organics; and secondly, removing nitrogen under aerobic and anoxic conditions [4]. The high biomass retention property of aerobic granular sludge enables the organic loading rate of a reactor to increase. A long sludge retention time is also especially beneficial to nitrifying bacteria. Aerobic and anoxic zones are present inside the granules, which can simultaneously conduct the nitrification and denitrification processes, and therefore nitrogen pollution in wastewater can be removed. Furthermore, aerobic granular sludge can be used to treat various wastewaters and is able to tolerate shock loading due to the unique granular structure and high biomass concentration in the reactor [5]. Aerobic granular sludge was first studied in an aerobic upflow sludge blanket reactor for municipal sewage treatment [6]. Other reactors with strong mixing ability were also employed for forming aerobic granular sludge, including a sequencing batch reactor (SBR) [7-9] and a sequencing batch airlift reactor (SBAR) [10-13]. The elliptical-shaped airflow improved the mixing speed in SBAR, inducing the granules become more compact and steady.

Most of the aerobic granule formation studies were carried out on synthetic wastewater consisting of glucose, sucrose, acetate, and ethanol [3, 9, 14-16], and some attempts have applied aerobic granular sludge in practical wastewater treatment for treating pollutants in domestic wastewater [17], municipal wastewater [7], and industrial wastewater treatments $[2,8,18]$. However, the aerobic granule formation in these cases remains unclear and the effect of aerobic granules on reducing organics in lots of industrial wastewater is lacking. Furthermore, there have been no reports regarding the use of aerobic granules on tapioca-processing wastewater - one of the most prevalent sources of pollution in Vietnam [19]. Therefore, this study aimed to investigate the formation and stabilization of aerobic granules from the acclimation stage to mature aerobic granules on tapioca-processing wastewater treatment. The performance of SBAR on treatment of the wastewater was measured in terms of removal efficiency of COD, nitrogen, and phosphorus.

\section{Experimental Procedures}

\section{Tapioca-Processing Wastewater and Seed Sludge Condition}

The wastewater sample used in this study was collected from the equalization tank of a tapioca processing factory in Tay Ninh Province, Vietnam. Samples were collected
Table 1. Characterization of raw tapioca-processing wastewater.

\begin{tabular}{|c|c|c|c|}
\hline Parameters & Unit & Values & $\begin{array}{c}\text { Vietnamese standard } \\
\text { of industrial } \\
\text { wastewater discharge } \\
\text { (Column B QCVN } \\
40: 2011 / \mathrm{BTNMT})\end{array}$ \\
\hline $\mathrm{pH}$ & - & $3.9-4.5$ & $5.5-9.0$ \\
\hline $\mathrm{COD}$ & $\mathrm{mg} / \mathrm{L}$ & $4,800-16,000$ & 150 \\
\hline $\mathrm{BOD}_{5}$ & $\mathrm{mg} / \mathrm{L}$ & $2,500-11,550$ & 50 \\
\hline $\mathrm{CN}^{-}$ & $\mathrm{mg} / \mathrm{L}$ & $2-75$ & 0.1 \\
\hline $\mathrm{SS}^{-}$ & $\mathrm{mg} / \mathrm{L}$ & $350-1,000$ & 100 \\
\hline $\mathrm{NH}_{4}^{+}-\mathrm{N}$ & $\mathrm{mg} / \mathrm{L}$ & $95-182$ & 10 \\
\hline $\mathrm{Total}^{-} \mathrm{N}$ & $\mathrm{mg} / \mathrm{L}$ & $145-470$ & 40 \\
\hline $\mathrm{PO}_{4}{ }^{3-}-\mathrm{P}$ & $\mathrm{mg} / \mathrm{L}$ & $127-432$ & 6 \\
\hline
\end{tabular}

and stored in $20-\mathrm{L}$ containers and kept at $4^{\circ} \mathrm{C}$ from February to September 2015. The composition of tapioca processing wastewater is given in Table 1 .

To enhance the development of microorganisms, the influent wastewater was supplemented by nutrient ingredients $(\mathrm{N}, \mathrm{P})$ and micronutrients at doses according to Wang et al. [20]. The composition of tapioca-processing wastewater is given in Table 1 . The biogas sludge was used for microbial cultivation with a mixed liquor suspended solid (MLSS) concentration of 3,627 $\mathrm{mg} / \mathrm{L}$ (VSS/SS ratio of $50 \%$ ). The $\mathrm{pH}$ value of influent wastewater was maintained at about 6.8-7.2 using $\mathrm{NaHCO}_{3} 1 \mathrm{M}$.

\section{Reactor Set-up}

Experiments were done in an open, cylindrical columntype SBAR, with a working volume of 3 L (Fig. 1). The reactor was made from $2 \mathrm{~mm}$ thick acrylic material,

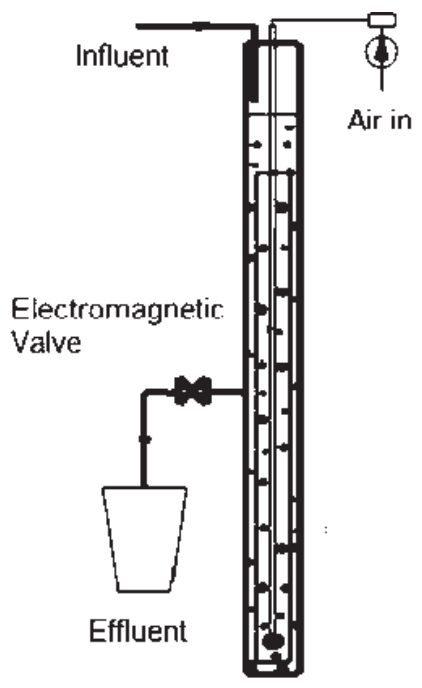

Fig. 1. Schematic diagram of sequencing batch airlift reactor (SBAR) setup. 
including two columns. The external column is $1,000 \mathrm{~mm}$ in height and has a diameter of $70 \mathrm{~mm}$. The internal column with a diameter of $40 \mathrm{~mm}$ and $700 \mathrm{~mm}$ height was positioned $15 \mathrm{~mm}$ from the bottom of the external column.

Air was introduced through a pumice stone located at the bottom of the reactor, and airflow rate of $5 \mathrm{~L} / \mathrm{min}$ was applied. The reactor has an automatic control system with an electromagnetic valve $400 \mathrm{~mm}$ above the bottom of the external column to drain the water $(50 \%$ of the water volume in the reactor was withdrawn).

\section{Experimental Procedure}

The reactor was operated in sequencing batch mode, feeding and withdrawing automatically. Each three-hour cycle consisted of four steps: $5 \mathrm{~min}$ of influent filling, 158-170 min of aeration, 3-15 min of settling, and 2 min of effluent withdrawal. Time for influent filling and effluent withdrawal remained consistent during the experiments while settling time was decreased step by step from $15 \mathrm{~min}$ to $3 \mathrm{~min}$ in the first two weeks to enhance the washing of poor-settling ability sludge and retained granules in which the settling velocity was around $8 \mathrm{~m} / \mathrm{h}$. The reactor was operated at the step-wise increased OLR of $2.5,3.2,5.0,7.5$, and $10 \mathrm{kgCOD} / \mathrm{m}^{3}$.day as presented in Table 2.

The experiments were executed in the laboratory at an ambient temperature ranging from 28 to $32^{\circ} \mathrm{C}$.

\section{Analytical Methods}

Wastewater samples taken from the reactor were analysed for dissolved oxygen (DO), $\mathrm{pH}, \mathrm{COD}$, total nitrogen (TN), $\mathrm{NH}_{4}^{+}-\mathrm{N}, \mathrm{NO}_{3}^{-}-\mathrm{N}, \mathrm{NO}_{2}^{-}-\mathrm{N}$, total phosphorus (TP), and alkalinity. The sludge samples were analyzed for mixed liquor suspended solids (MLSS), mixed liquor volatile suspended solids (MLVSS), and sludge volume index (SVI), as well as diameter, surface structure, and inner microbial organization of the granules. DO and $\mathrm{pH}$ were determined by the electrode probe using a portable Hach pH/DO meter (HQ40d model). COD, N, P, SS, and SVI were examined according to the standard methods [21].

Granule diameter was characterized using an Olympus BX 51 microscope with attached DP 71 camera and image analysis software. The sludge structure and inner microbial organization were determined according to the crystal violet method [22].

All experiments were performed in triplicate and the average values were reported.

Table 2. Organic loading rate (OLR) over the entire experimental period.

\begin{tabular}{|c|c|c|c|c|c|}
\hline Week & $1-3$ & $4-8$ & $9-14$ & $15-16$ & $17-18$ \\
\hline OLR, $\mathrm{kgCOD} / \mathrm{m}^{3}$.day & 2.5 & 3.2 & 5.0 & 7.5 & 10 \\
\hline
\end{tabular}

a)

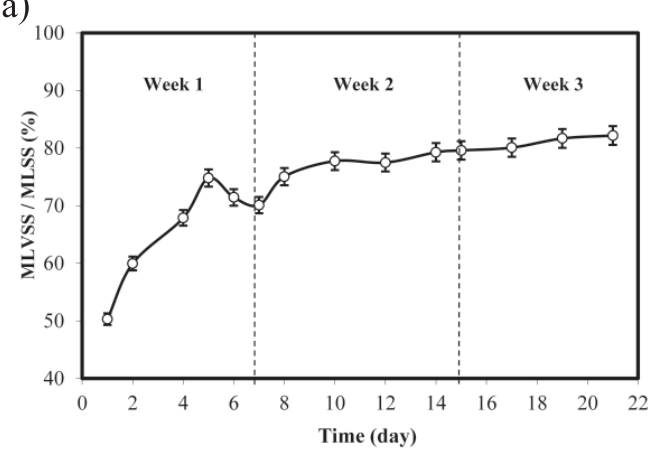

b)

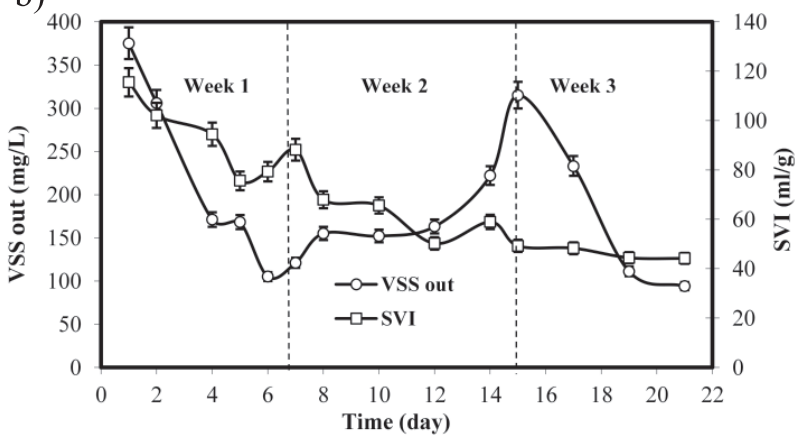

Fig. 2. Change of: a) MLVSS/MLSS ratio and b) VSS concentration in effluent and SVI in reactor at OLR of $2.5 \mathrm{kgCOD} / \mathrm{m}^{3} \cdot$ day.

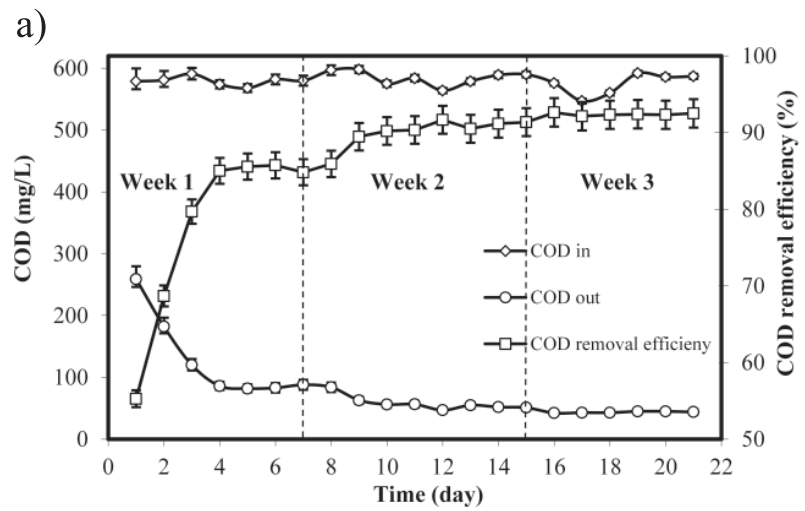

b)

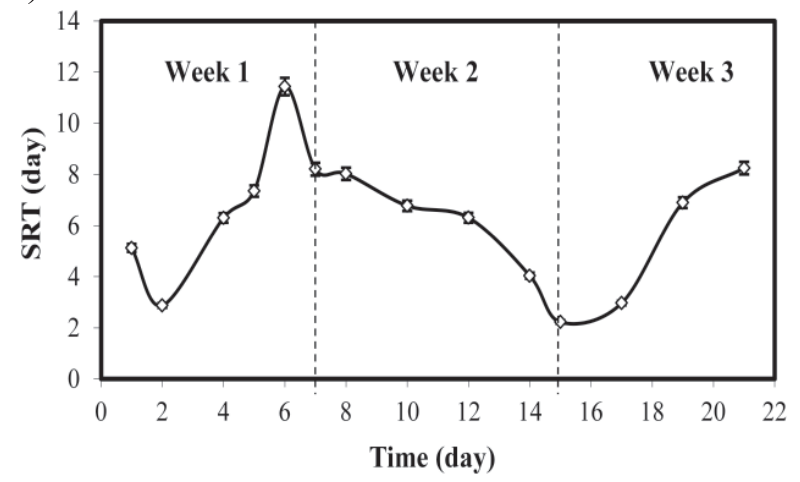

Fig. 3. Change of: a) COD and b) sludge retention time at OLR of $2.5 \mathrm{~kg} \mathrm{COD} / \mathrm{m}^{3}$.day. 


\section{Results and Discussion}

\section{Formation and Stabilization of Aerobic Granules}

After one week of acclimation at the organic loading rate (OLR) of $2.5 \mathrm{kgCOD} / \mathrm{m}^{3}$.day, anaerobic biogas sludge was transformed completely into aerobic sludge, as indicated by the color of the sludge turning from black
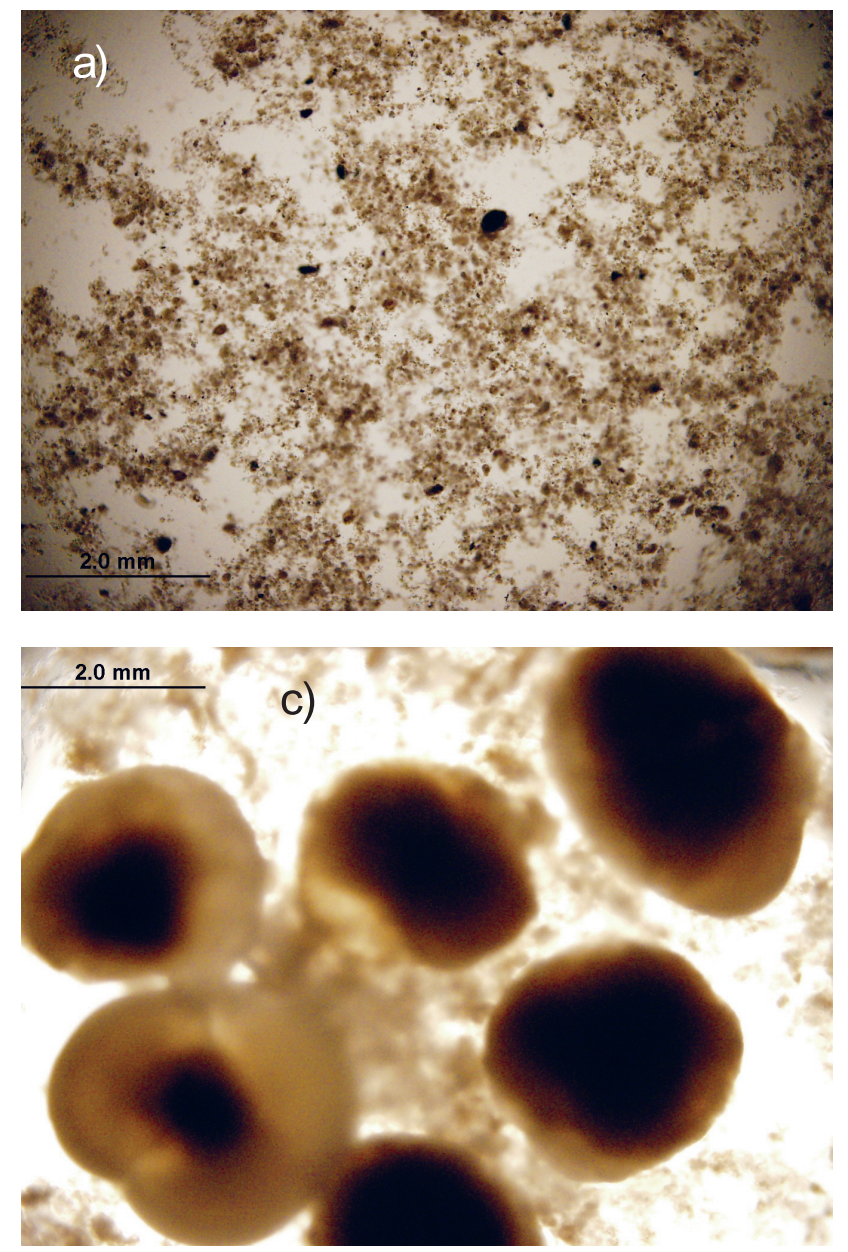

d)
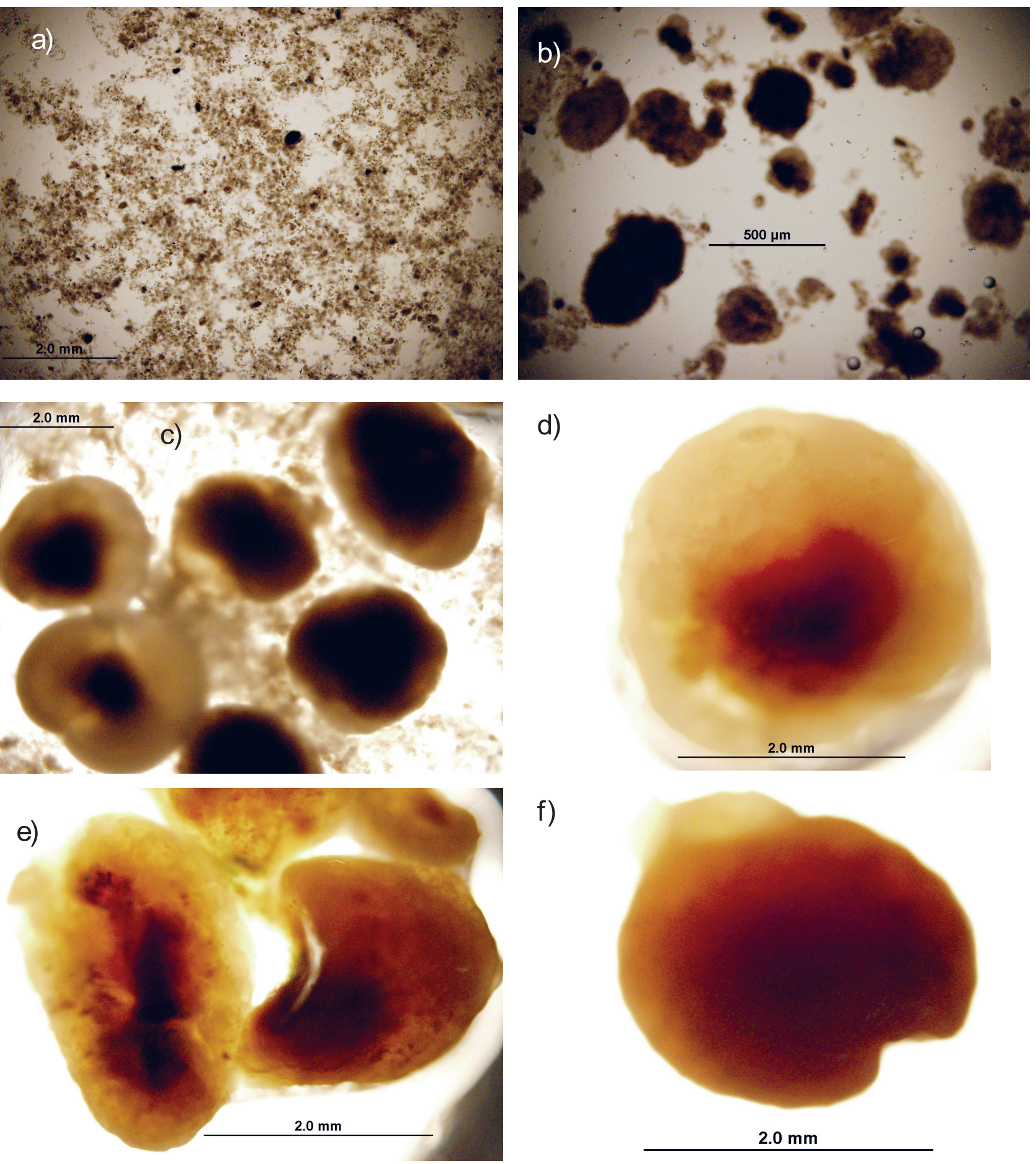

f)

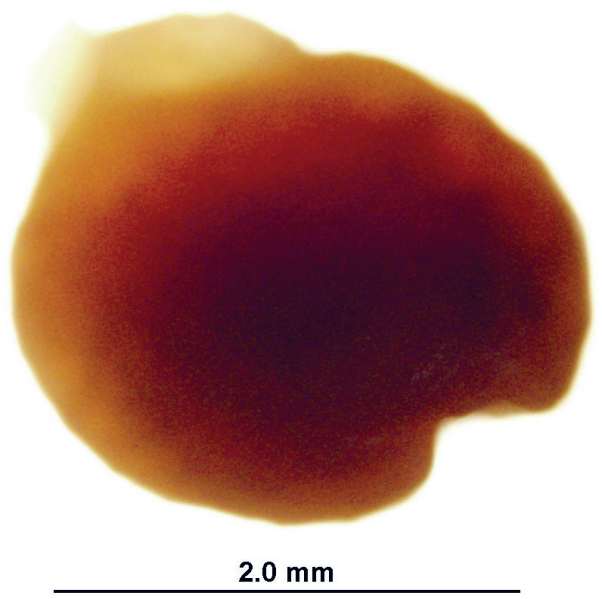

Fig. 4. Granules in different weeks: a) seed sludge, b) small granules in the third week, c) mature granules after week 10, d) mature granule at week 16, e) broken granules, and f) granular core. 
the reactor declined while the concentration of volatile suspended solid (VSS) of effluent increased from $152 \mathrm{mg} / \mathrm{L}$ up to $325 \mathrm{mg} / \mathrm{L}$ on the day 15 (Fig. 2b) and short sludge age varied between 2-6 days (Fig. 3b). From the third week forward, the settling time was maintained at a constant value of $3 \mathrm{~min}$. At this time, color of the sludge switched from dark brown to light brown, and sludge flocs had a tendency to segregate. The small granules appeared to be streak-shaped, which had an average diameter of $200 \mu \mathrm{m}$ (Fig. 4b). As the granules were formed; the rate of MLVSS/MLSS also increased rapidly and reached more than $80 \%$ (Fig. 2a), and SVI was lower than $50 \mathrm{~mL} / \mathrm{g}$ due to the increase in the dimension of granules.

Obviously, operating the reactor with the step-wise decreased settling time, the period time for small granules appearing in this experiment was similar to the results of other studies, often after an operational 2-3 weeks [23-25]. However, physical characteristic of granules were different due to various operational conditions. These variations in characteristics of granules could be recorded in the reports of Kong et al. [23] and Liu and Tay [25]. While at similar operating conditions with an OLR of $3 \mathrm{~kg} \mathrm{COD} / \mathrm{m}^{3}$.day and hydraulic retention time (HRT) of $4 \mathrm{~h}$, Kong et al. [23] cultivated small aerobic granules after two weeks in the acetate-based synthetic wastewater. The granules reached an average diameter of about $200 \mu \mathrm{m}$, and SVI $70 \mathrm{~mL} / \mathrm{g}$. Liu and Tay [25] got the aerobic granules with SVI increased from $108 \mathrm{mg} / \mathrm{L}$ to around $170 \mathrm{~mL} / \mathrm{g}$. An explanation for these variations could be the high OLR of $8 \mathrm{kgCOD} / \mathrm{m}^{3}$.day, which could promote granulation with larger dimensions but let structure loose, which may lead to higher VSI in the first two weeks. Therefore, acclimatizing the operation to the moderate OLR-induced the formation of granules had a more compact structure $[20,24]$.

To investigate the effect of the OLR on stability of aerobic granules, the OLR increased gradually from $3.2 \mathrm{~kg} \mathrm{COD} / \mathrm{m}^{3}$.day up to $10 \mathrm{~kg} \mathrm{COD} / \mathrm{m}^{3}$.day. Along with an increase in OLR, granules appeared and increased in both diameter and density (Fig. 5). The structure of granules reached stability at a diameter of $2 \mathrm{~mm}$ after being operational for 10 weeks (Fig. 4c) and maintained stability until the week 16 at a diameter of $2.5 \mathrm{~mm}$, when the OLR rose to $7.5 \mathrm{~kg} \mathrm{COD} / \mathrm{m}^{3}$.day (Fig. $4 \mathrm{~d}$ ). The mature granules had a compact structure, and round and smooth surface included the dark core with the presence of dead cells and anaerobic bacteria, and surroundings were a yellow aerobic layer with the presence of nitrification and heterotrophic bacteria. Most other research has produced similar results in the structure of aerobic granules, which included the interior and surrounding anaerobic layers $[26,27]$. Up to operational condition, the mature granules had an average diameter in the range of $1.5-3 \mathrm{~mm}$ and SVI of around $50 \mathrm{~mL} / \mathrm{g}$. These results correspond with average granule diameter of $1.8 \mathrm{~mm}$ and SVI of $50 \mathrm{mg} / \mathrm{L}$ after 16 weeks of operation [23]. This implies that tapiocaprocessing wastewater was in good condition for granule formation.

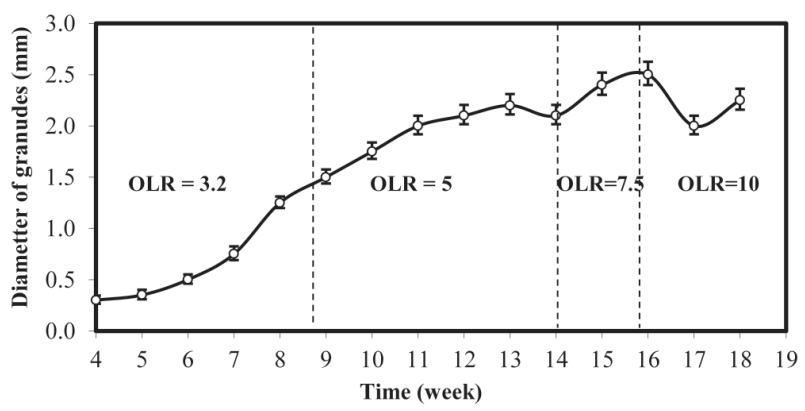

Fig. 5. Change in granule diameter at different OLRs $\left(\mathrm{kgCOD} / \mathrm{m}^{3}\right.$.day).
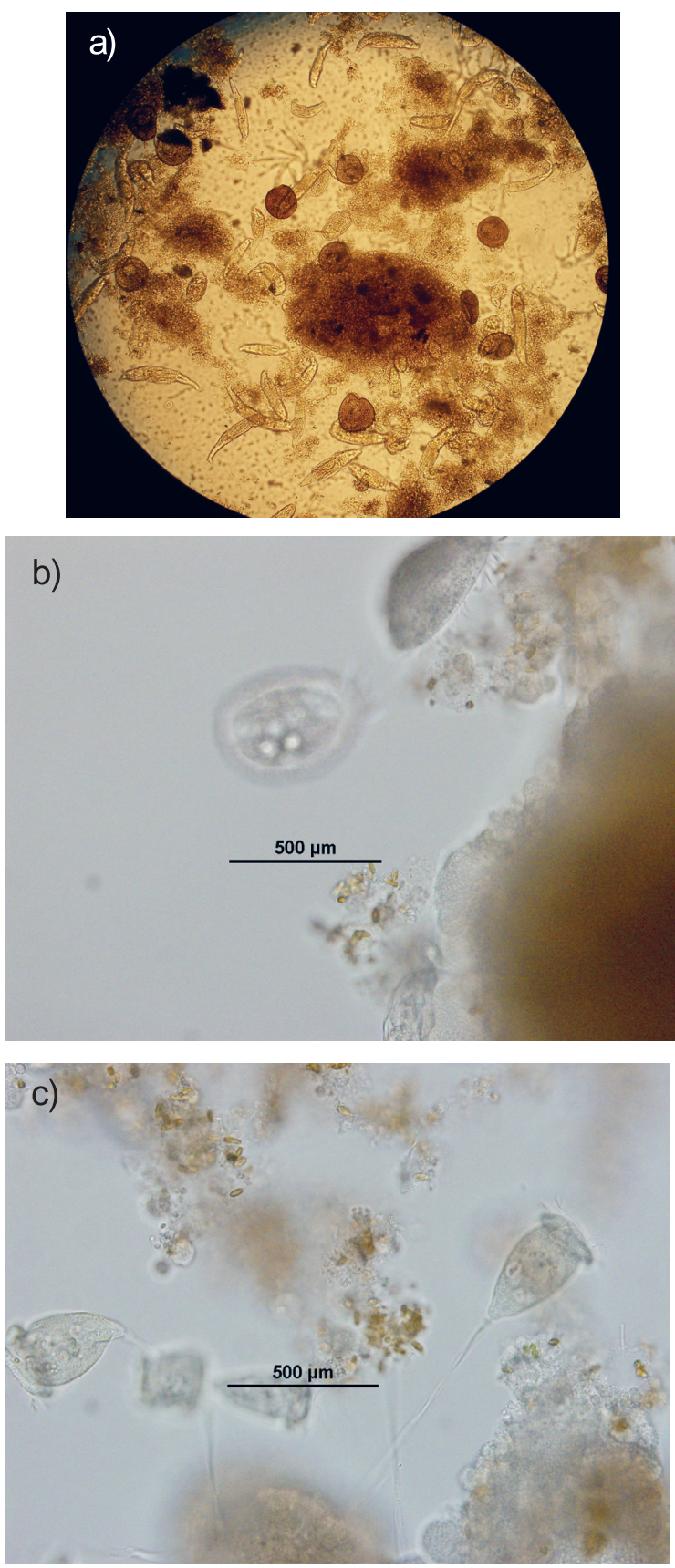

Fig. 6. Protozoa in sludge: a) crawling ciliates, b) free-swimming ciliates, and c) stalked ciliates. 
a)

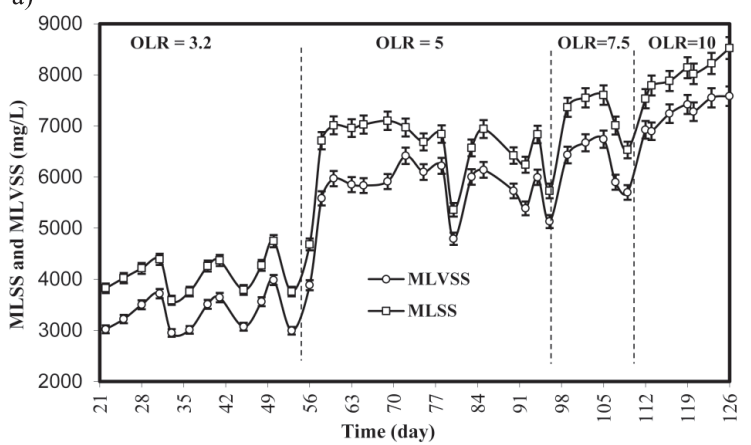

b)

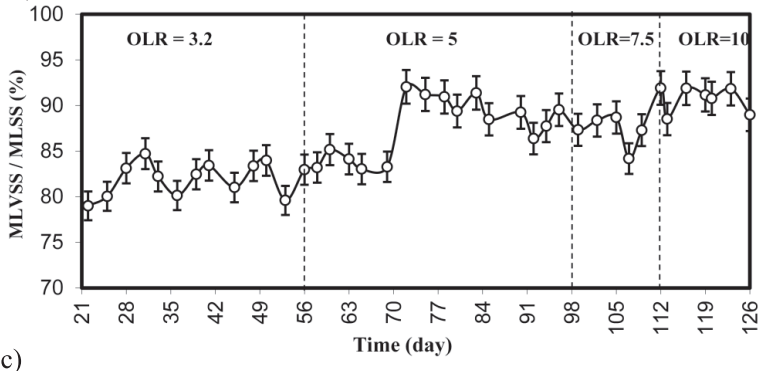

c)

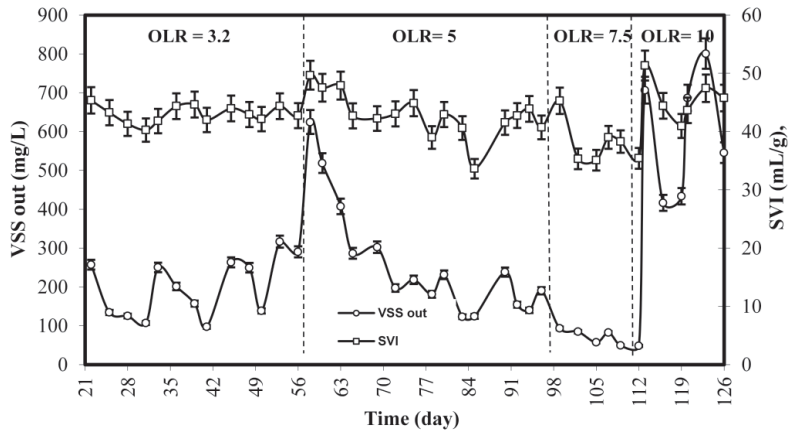

Fig. 7. Variation in parameters at different OLRs: a) MLSS, MLVSS concentration, b) MLVSS/MLSS ratio, and c) $\mathrm{VSS}_{\text {out }}$ and SVI.

However, when the OLR rose to $10 \mathrm{~kg} \mathrm{COD} / \mathrm{m}^{3}$.day, the diameter increased to 3-4 $\mathrm{mm}$. This was difficult for the substances diffusing into the granules' core, which caused the granules to crack (Fig. 4e). As a result, the outer layer was broken while the black core remained (Fig. 4f). Subsequently, the broken granules recovered quickly, aggregated, and increased the biomass. Since the large granules had a thick anaerobic layer induced to anaerobic fermentation that released biogas, organic acid could disintegrate these granules [26]. Obliviously, aerobic granules were stable at the maximum OLR of $7.5 \mathrm{~kg} \mathrm{COD} / \mathrm{m}^{3}$.day in the operational condition of this experiment. At this OLR, the granules had compact structure and good settling ability indicated by the low SVI of around 35-40 $\mathrm{mL} / \mathrm{g}$ and VSS concentration in the effluent lower than $100 \mathrm{mg} / \mathrm{L}$ (Fig. 7c). The trends of granules characteristic during OLR variation were also described by Liu and Tay [25], who successfully cultivated aerobic granules at the high OLR of $12 \mathrm{~kg} \mathrm{COD} / \mathrm{m}^{3}$.day and maintained the stability of granules (SVI lower than $100 \mathrm{mg} / \mathrm{L}$ and size $0.8 \mathrm{~mm}$ ) at low OLR of $6 \mathrm{~kg} \mathrm{COD} / \mathrm{m}^{3}$.day after two weeks of operation. a)

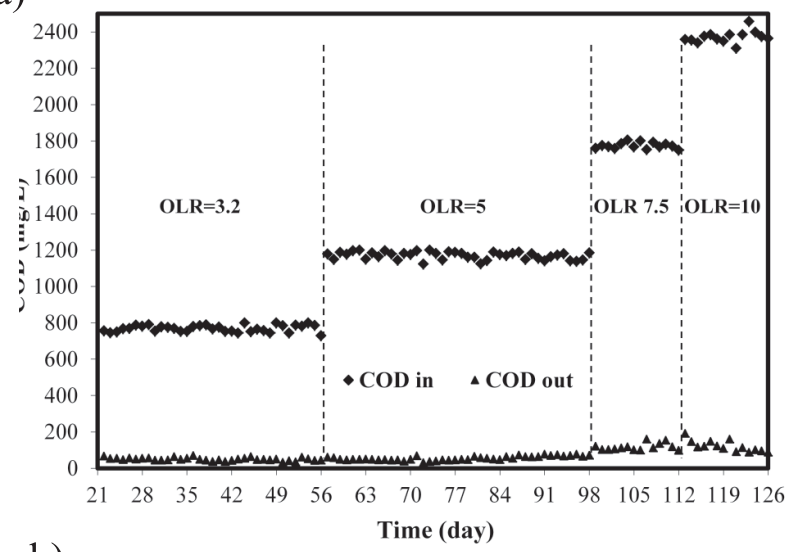

b)

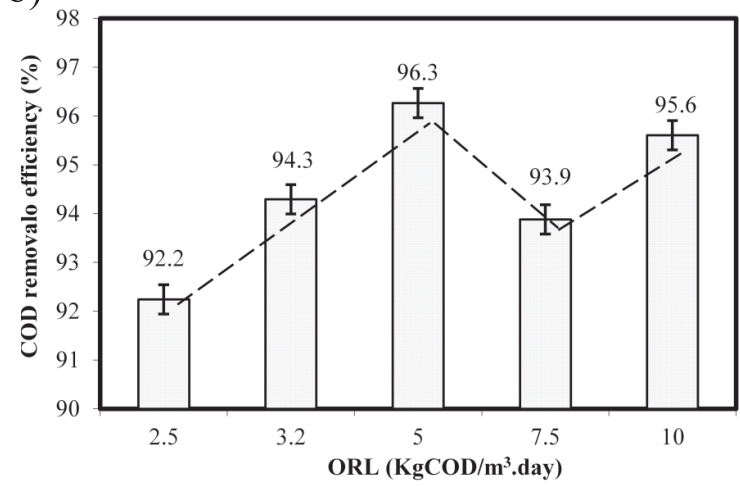

Fig. 8. a) COD concentrations in the influent and effluent and b) COD removal efficiency at different OLRs.

\section{Substrate Removal Efficiency}

After two weeks of operation, the rate of MLVSS/ MLSS increased to the value of $79 \%$ and protozoa appeared abundantly in the sludge, while ciliates were predominant (Fig. 6). At the same time, chemical oxygen demand (COD) removal efficiency increased from $55.3 \%$ to a stable value of $90-91 \%$ at the end of the second week (Fig. $3 a)$. In the third week, biomass in the reactor decreased further to $2,764 \mathrm{mg} / \mathrm{L}$. However, COD removal efficiency was still higher than $92 \%$, which is due to granules with high density of microorganisms increasing substance removal efficiency. From week 11 the development of granules according to the rise of OLR induced increases of MLVSS concentration and rate of MLVSS/MLSS up to more than $85 \%$ (Figs $7 \mathrm{a}$ and $7 \mathrm{~b}$ ), and COD removal efficiency rose to $93.9-96.3 \%$ simultaneously (Fig. 8 b).

The results of monitoring the variation of COD and dissolve oxygen (DO) in a stable cycle at the OLR of $5 \mathrm{kgCOD} / \mathrm{m}^{3}$.day showed that the substances were consumed quickly and fell to $60 \%$ in the first 20 minutes of aeration. Up to 40 minutes, more than 95\% COD was removed. For the remaining aeration period, cell degradation occurred in the reactor and the extra cellular polymers were the adhesives that stuck the bacteria together. The elliptical-shaped airflow rolled the flocs into granules. The substance famine was identified by a sudden increase of DO while COD value decreased quickly from 

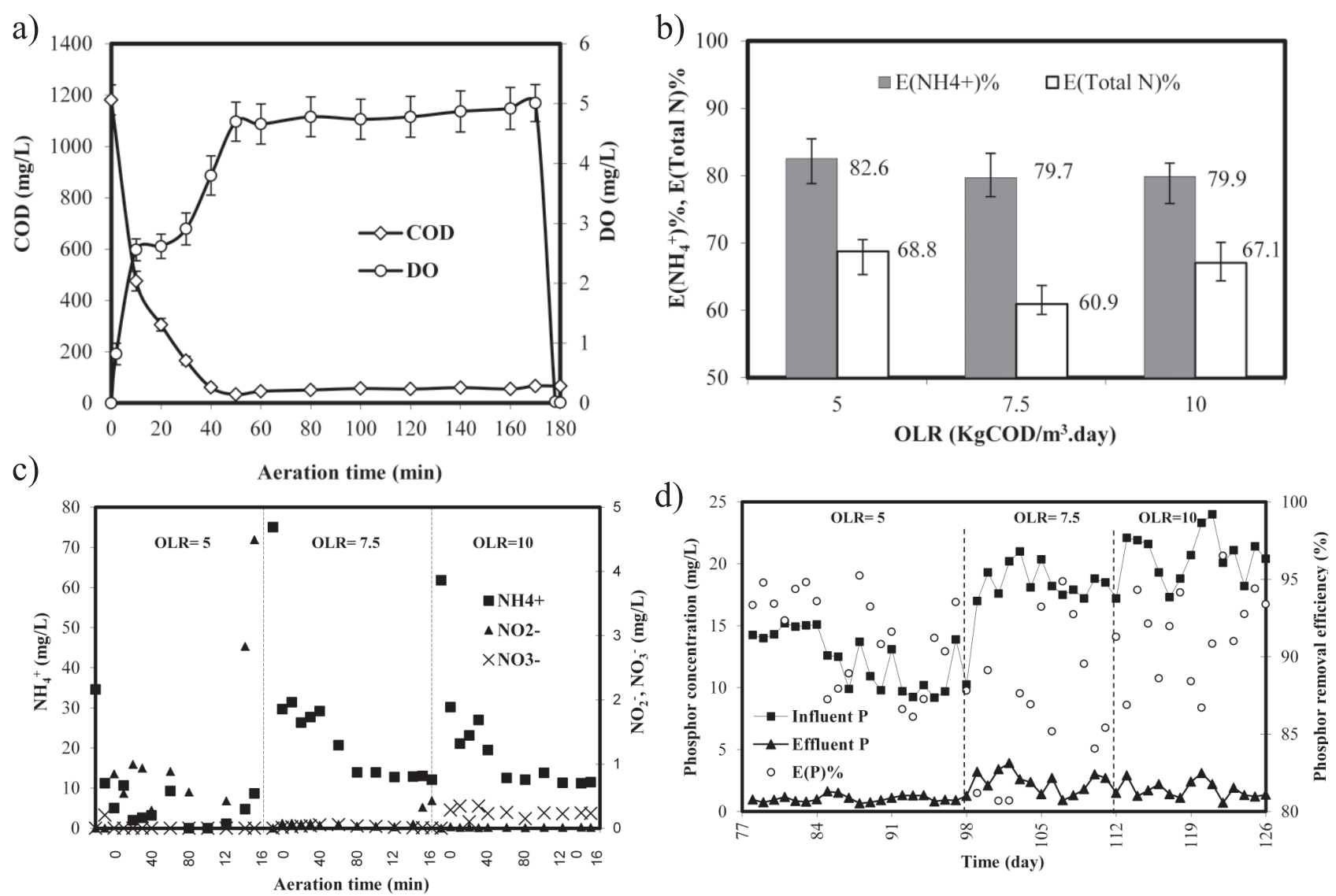

Fig. 9. Variations of: a) COD and DO to aeration time at the OLR of $5 \mathrm{~kg} \mathrm{COD} / \mathrm{m}^{3}$.day, b) $\mathrm{NH}_{4}^{+}-\mathrm{N}$ and total $\mathrm{N}$ removal efficiency to different OLRs, c) P removal efficiency to different OLRs, and d) $\mathrm{NH}_{4}^{+}-\mathrm{N}, \mathrm{NO}_{2}^{-}-\mathrm{N}$, and $\mathrm{NO}_{3}^{-}-\mathrm{N}$ to aeration time.

1,200 $\mathrm{mg} / \mathrm{L}$ to less than $50 \mathrm{mg} / \mathrm{L}$ (Fig. 9a). When the substance concentration remained high, the DO value in the reactor was quite low due to substance transformation and degradation.

Moreover, nitrogen and phosphorus removal also occurred simultaneously in the reaction tank. A significant decrease in $\mathrm{NH}_{4}^{+}-\mathrm{N}$ and $\mathrm{TP}$ values served as evidence of high removal efficiency. These values were $79.7-82.6 \%$ and $80-95 \%$ for $\mathrm{NH}_{4}^{+}-\mathrm{N}$ and TP at different OLRs, respectively (Figs 9b, 9c, and 9d). Meanwhile, $\mathrm{NO}_{2}^{-}-\mathrm{N}$ and $\mathrm{NO}_{3}^{-}-\mathrm{N}$ after treatment did not increase significantly, whichindicated thatmostorganic $\mathrm{Nand} \mathrm{NH}_{4}{ }^{+} \mathrm{N}$ were converted into biomass. The remnant was transferred into nitrate, and nitrite and was evaporated as freeammonia. Total nitrogen removal efficiency was low at $60.9-68.8 \%$ due to high DO, and low COD in the substance famine phase does not created favourable conditions for denitrification. Low nitrogen removal efficiency was also reported in [28]. At the operation mode without control of dissolve oxygen (DO), the maximum of total inorganic nitrogen (TIN) removal efficiencies reached 67.8-71.5\%. Especially, Liu et al. [29, 30]got around 50\% for total nitrogen removal efficiency in pilot-scale SBRs for real wastewater treatment. They concluded that to improve TIN removal efficiency, the operation mode should control DO or alternating anoxic/oxic combined with the step-feeding mode, which supplies substrate for denitrification.

\section{Conclusions}

The formation of aerobic granules in SBAR using tapioca-processing wastewater as a substrate is visual evidence of successful aerobic granulation in a practical scenario. Aerobic granules quickly increased their density and diameter, which were maintained to a mean size of $2.5 \mathrm{~mm}$ at an OLR of $7.5 \mathrm{kgCOD} / \mathrm{m}^{3}$.day after 15 weeks' operation. Moreover, a high MLVSS/MLSS ratio of $80-90 \%$, low SVI of $30-50 \mathrm{~mL} / \mathrm{g}$, the stronger and more compact structure of aerobic granular sludge, as well as high $\mathrm{COD}, \mathrm{NH}_{4}^{+}-\mathrm{N}$, and TP removal efficiency of $93.9-96.3 \%, 79.7-82.6 \%$, and $80-95 \%$ respectively, confirmed the superiority of aerobic granules in SBAR over conventional activated sludge.

\section{Acknowledgements}

This work was supported by the Institute for Environment and Resources and the University of Technology, Vietnam National University - Ho Chi Minh City. 


\section{References}

1. LIU L., WANG Z., YAO J., SUN X., CAI W. Investigation on the properties and kinetics of glucose-fed aerobic granular sludge. Enzyme Microb. Technol. 36 (2-3), 307, 2005.

2. WANG S.G., LIU X.W., GONG W.X., GAO B.Y., ZHANG D.H., YU H.Q. Aerobic granulation with brewery wastewater in a sequencing batch reactor. Bioresour. Technol. 98 (11), 2142, 2007.

3. ADAV S., LEE D.J., LAI J.Y. Potential cause of aerobic granular sludge breakdown at high organic loading rates. Appl. Microbiol. Biotechnol. 85, (5), 1601, 2010.

4. GAO D., LIU L., LIANG H., WU W.-M. Aerobic granular sludge: characterization, mechanism of granulation and application to wastewater treatment. Crit. Rev. Biotechnol. 31 (2), 137, 2011.

5. MOY B.P., TAY J.H., TOH S.K., LIU Y., TAY S.L. High organic loading influences the physical characteristics of aerobic sludge granules. Lett. Appl. Microbiol. 34 (6), 407, 2002.

6. MISHIMA K., NAKAMURA M. Self-immobilization of aerobic activated sludge - a pilot study of the aerobic upflow sludge blanket process in municipal sewage treatment. Water Sci. Technol. 23 (4-6), 981, 1991.

7. TU X., SU B.S., LI X.N., ZHU J.R. Characteristics of extracellular fluorescent substances of aerobic granular sludge in pilot-scale sequencing batch reactor. J. Cent. South Univ. Technol. 17 (3), 522, 2010.

8. WEI D., QIAO Z., ZHANG Y., HAO L., SI W., DU B., WEI Q. Effect of COD/N ratio on cultivation of aerobic granular sludge in a pilot-scale sequencing batch reactor. Appl. Microbiol. Biotechnol. 97 (4), 1745, 2013.

9. YUAN X., GAO D., LIANG H. Reactivation characteristics of stored aerobic granular sludge using different operational strategies. Appl. Microbiol. Biotechnol. 94 (5), 1365, 2012.

10. WANG S., SHI W., YU S., YI X., YANG X. Formation of aerobic granules by $\mathrm{Mg}^{2+}$ and $\mathrm{Al}^{3+}$ augmentation in sequencing batch airlift reactor at low temperature. Bioprocess Biosyst. Eng. 35 (7), 1049, 2012.

11. BAO R., YU S., SHI W., ZHANG X., WANG Y. Aerobic granules formation and nutrients removal characteristics in sequencing batch airlift reactor (SBAR) at low temperature. J. Hazard. Mater. 168 (2-3), 1334, 2009.

12. THANH B.X., SPERANDIO M., GUIGUI C., AIM R. B., WAN J., VISVANATHAN C. Coupling sequencing batch airlift reactor (SBAR) and membrane filtration: Influence of nitrate removal on sludge characteristics, effluent quality and filterability. Desalination. 250 (2), 850, 2010.

13. WAN J., BESSIERE Y., SPERANDIO M. Alternating anoxic feast/aerobic famine condition for improving granular sludge formation in sequencing batch airlift reactor at reduced aeration rate. Water Res. 43 (20), 5097, 2009.

14. QUAN X., MA J., XIONG W., WANG X. Bioaugmentation of half-matured granular sludge with special microbial culture promoted establishment of 2,4-dichlorophenoxyacetic acid degrading aerobic granules. Bioprocess Biosyst. Eng. 38 (6), 1081, 2015.

15. YARLAGADDA V., KADALI R., SHARMA N., SEKAR R., VAYALAM PURATH V. Rapid Establishment of p-Nitrophenol Biodegradation in Acetate-Fed Aerobic Granular Sludge. Appl. Biochem. Biotechnol. 166 (5), 1225, 2012.
16. PRONK M., ABBAS B., AL-ZUHAIRY S.H.K., KRAAN R., KLEEREBEZEM R., VAN LOOSDRECHT M.C.M. Effect and behaviour of different substrates in relation to the formation of aerobic granular sludge. Appl. Microbiol. Biotechnol. 99 (12), 5257, 2015.

17. KHOKHLACHEV N., KALENOV S., ZANINA O., TYUPA D., BAURINA M., KUZNETSOV A. The role of stress agents as operating factors in formation and functioning of granular aerobic activated sludge at model domestic wastewater treatment. Bioprocess Biosyst. Eng. 37 (9), 1771, 2014.

18. ARROJO B., MOSQUERA-CORRALA., GARRIDO J. M., MÉNDEZ R. Aerobic granulation with industrial wastewater in sequencing batch reactors. Water Res. 38 (14-15), 3389, 2004.

19. HIEN P.G., OANH L.T.K., VIET N.T., LETTINGA G. Closed wastewater system in the tapioca industry in vietnam. Water Sci. Technol. 39 (5), 89, 1999.

20. WANG F., YANG F.-L., ZHANG X.-W., LIU Y.-H., ZHANG H.-M., ZHOU J. Effects of cycle time on properties of aerobic granules in sequencing batch airlift reactors. World J. Microbiol. Biotechnol. 21 (8-9), 1379, 2005.

21. FEDERATION W.E., ASSOCIATION A.P.H. Standard methods for the examination of water and wastewater. American Public Health Association (APHA): Washington, DC, USA. 2005.

22. CONN H.J., HUCKER G.J. Further Studies On The Methods of Gram Staining. Tech. Bull. 128 (1), 1, 1927.

23. KONG Y., LIU Y.-Q., TAY J.-H., WONG F.-S., ZHU J. Aerobic granulation in sequencing batch reactors with different reactor height/diameter ratios. Enzyme Microb. Technol. 45 (5), 379, 2009.

24. LIU Y.-Q., MOY B. Y.-P., TAY J.-H. COD removal and nitrification of low-strength domestic wastewater in aerobic granular sludge sequencing batch reactors. Enzyme Microb. Technol. 42 (1), 23, 2007.

25. LIU Y.-Q., TAY J.-H. Fast formation of aerobic granules by combining strong hydraulic selection pressure with overstressed organic loading rate. Water Res. 80, 256, 2015.

26. TAY J.H., IVANOV V., PAN S., TAY S.L. Specific layers in aerobically grown microbial granules. Lett. Appl. Microbiol. 34 (4), 254, 2002

27. DERELI R.K., ERSAHIN M.E., OZGUN H., OZTURK I., JEISON D., VAN DER ZEE F., VAN LIER J.B. Potentials of anaerobic membrane bioreactors to overcome treatment limitations induced by industrial wastewaters. Bioresour. Technol. 122, 160, 2012.

28. CHEN F.-Y., LIU Y.-Q., TAY J.-H., NING P. Alternating anoxic/oxic condition combined with step-feeding mode for nitrogen removal in granular sequencing batch reactors (GSBRs). Sep. Purif. Technol. 105, 63, 2013.

29. LIU Y.-Q., MOY B., KONG Y.-H., TAY J.-H. Formation, physical characteristics and microbial community structure of aerobic granules in a pilot-scale sequencing batch reactor for real wastewater treatment. Enzyme Microb. Technol. 46 (6), 520, 2010.

30. LIU Y.-Q., KONG Y., TAY J.-H., ZHU J. Enhancement of start-up of pilot-scale granular SBR fed with real wastewater. Sep. Purif. Technol. 82, 190, 2011. 